\title{
Konstruksi Sosial Pekerja Perempuan dan Anak pada Industri Perikanan
}

\author{
Anggaunitakiranantika \\ Fakultas IImu Sosial, Universitas \\ Negeri Malang \\ email: anggaunita.fis@um.ac.id
}

\begin{abstract}
Women worker and children employee on fishery industry aims to increase workforce participation around seashore edge beside budgeting pressure for labor cost. What is more necessary, the fishery industry is known as fishing manufacture in Pasuruan, tend to save their expenditure budget due to social subsidies to their employee. Thirty-four women who work at fishery industry was aged from 18 to 55 years old and the 8 children who engage with work was aged from 8 to 16 years old. There was wage gap between women worker and children worker. Gender dualism belongs to women worker and the children create social construction among local society in Pasuruan. Social construction happened because of dichotomy aspect. The first is working in the fishery industry was done with pride in breaking patriarchy rules, Secondly, they set to work for long-life family needed.
\end{abstract}

Keywords: industry; fishery; social construction; women worker; children worker

\begin{abstract}
Abstrak: Masuknya pekerja perempuan dan anakyang bekerja di dalam sektor industri di pesisir pantai Pasuruan selain didasari dengan mengangkat partisipasi kerja bagi penduduk di sekitar wilayah pantai dengan tujuan menekan pengeluaran untuk membayar buruh. Di samping itu, perusahaan atau pelaku industri perikanan berupa pengolahan ikan di Pasuruan juga dapat berhemat karena tidak perlu memberi tunjangan sosial karena tidak ada tanggungan keluarga. Perempuan yang bekerja di sektor perikanan di Pasuruan sebagian besar adalah tenaga produktif yang rata-rata usianya berada dalam rentang usia 18-55 tahun sebanyak 34 orang dan anak anak berusia 916 tahun sebesar 8 anak. Terdapat perbedaan upah yang diterima antara pekerja perempuan dan pekerja anak. Dualisme Gender yang dimiliki oleh pekerja perempuan dan anak membentuk konstruksi sosial. Konstruksi sosial yang terjadi dalam pekerja perempuan dan anak nelayan adalah bekerja di industri pengolahan ikan dilakukan dengan rasa bangga karena mampu keluar dari sistem patriarkhi dan penemuhan kebutuhan dalam jangka panjang.
\end{abstract}

Kata Kunci: industri; perikanan; konstruksi sosial; pekerja perempuan; pekerja anak 


\section{A. Pendahuluan}

Provinsi Jawa Timur merupakan sebuah provinsi di Indonesia yang memiliki garis pantai yang panjang, membentang sepanjang $3120 \mathrm{~km}$. Kawasan pesisir Jawa Timur tidak luput dari jangkauan pembangunan hal ini disebabkan peningkatan jumlah penduduk, kebutuhan masyarakat dan konsumsi hasil laut menyebabkan pemanfaatan sumberdaya pesisir dan laut meningkat cepat. Pada hakikatnya pembangunan perikanan merupakan kegiatan untuk meningkatkan pendapatan dan kesejahteraan nelayan melalui pengelolaan sumber daya alam dengan faktor produksi berupa tenaga kerja manusia, teknologi dan modal.

Pembangunan dewasa ini tidak bisa lepas dari faktor ekonomi. Salah satu aspek kegiatan ekonomi ini yakni pengembangan wiraswasta yang ditujukan untuk membimbing dan meningkatkan daya kemampuan golongan ekonomi lemah. Industri merupakan salah satu jalan yang dipilih masyarakat dalam berwiraswasta. Dapat dipahami bahwa industrial berarti industri atau perindustrian (perusahaan), biasanya merupakan lembaga atau organisasi pemroduksian barang atau jasa. ${ }^{1}$

Industri kecil adalah lembaga atau organisasi yang memproduksi barang dan jasa, memiliki pekerja yang sedikit, memiliki ruang lingkup wilayah yang kecil, wilayah pemasaran lokal serta berorientasi untuk memperoleh keuntungan. Industri kecil yang ada di Indonesia merupakan industri yang digunakan dalam rangka memenuhi kebutuhan. Industri kecil berkembang seiring dengan kebutuhan manusia yang terus meningkat dan beragam.

Industri kecil menengah sebagai suatu bentuk usaha untuk mengembangkan ekonomi kerakyatan serta berdampak meningkatkan perekonomian masyarakat. Industri kecil menegah merupakan salah satu solusi yang dapat digunakan oleh pemerintah maupun masyarakat dalam usahanya untuk mengatasi jumlah pencari kerja yang melebihi lowongan pekerjaan yang ada di masyakarakat. Salah satu industri kecil menegah yang bergerak di sektor perikanan adalah pengolahan ikan di wilayah pesisir Pasuruan.

1S. R. Parker, R. K. Brown, dan M. A. Smith, Sosiologi Industri (Jakarta: Rineka Cipta, 1992), 30. 
Letak geografis pesisir Pasuruan sebagian besar dibatasi oleh laut. Maka terciptalah karakteristik tersendiri bagi penduduknya untuk memanfaatkan sumber daya laut sebagai mata pencahariannya, yakni sebagai nelayan. Seperti yang kita ketahui bahwa profesi nelayan sangat membutuhkan totalitas yang tidak hanya tenaga dan waktu. Tetapi juga keterlibatan seluruh anggota keluarga termasuk anak dan istri. Mulai dari mempersiapkan keperluan sebelum berlayar hingga menjual sendiri hasil tangkapannya untuk memenuhi kebutuhan hidup sehari-hari. Sebagian besar anak dan perempuan pekerja di Pasuruan masuk dalam sektor perikanan terutama bagi mereka yang tinggal di daerah pesisir yang merupakan keluarga dari nelayan tradisional di pesisir Pasuruan.

Kehidupan keluarga nelayan diidentikkan dengan kehidupan musiman yang dipengaruhi oleh ketergantungan terhadap alam yang akan mempengaruhi banyaknya hasil tangkapan ikan. Saat air laut pasang dan bukan musim ikan pada umumnya nelayan di Pasuruan tidak pergi melaut karena kondisi alam yang tidak bersahabat dan hasil laut akan sulit didapat. Nelayan di pesisir Pasuruan adalah nelayan tradisional dengan peralatan tangkap yang sederhana. Mereka menangkap jenis ikan dasar seperti ikan kerapu, ikan kakap merah, ikan belanak dan beberapa jenis ikan lainnya untuk dijual ke tengkulak pasar di Pasuruan atau Probolinggo. Keluarga nelayan umumnya adalah kelompok masyarakat desa pantai yang paling miskin dan tidak berdaya. Dikatakan tidak berdaya karena mereka rawan menjadi korban eksploitasi para tengkulak besar. Dikatakan miskin, karena perbulan penghasilan mereka sekeluarga rata-rata hanya berkisar Rp. 250.000 - Rp. 500.000. ${ }^{2}$

Dengan rasionalitas mendasar inilah, perempuan dan anak pada keluarga nelayan memilih untuk meninggalkan jerat kemiskinan yang berada di depan mata dengan menjadi pekerja dalam industri pengolahan ikan dan hasil laut lainnya di Pasuruan, Jawa Timur. Penelitian mengenai keluarga nelayan telah banyak dipublikasikan namun kehidupan mengenai perempuan dan anak yang merupakan bagian dari nelayan sekaligus pekerja dalam industri perikanan sangat menarik untuk diteliti. 2009), 29

${ }^{2}$ Kusnadi, Keberdayaan Nelayan dan Dinamika Ekonomi Pesisir (Yogyakarta: Ar-Ruzz Media, 
Dalam metodologi penelitian, terdapat sebuah paradigma yang diartikan sebagai anggapan-anggapan meta-teoritis yang paling mendasar yang menentukan kerangka pikir, mengandaikan dan cara bekerjanya para penganut teori sosial yang menggunakannya. ${ }^{3}$ Di dalamnya tersirat adanya kesamaan pandangan yang mengikat sekelompok penganut teori dalam cara pandang dan cara kerja yang sama dalam batas-batas pengertian yang sama pula. Jika para ilmuwan sosial telah menggunakan paradigma tertentu, maka berarti memandang dunia dalam suatu cara yang tertentu pula.

Dalam penelitian ini, menggunakan pendekatan kualitatif dalam analisis sosialnya, menggunakan paradigm definisi sosial, penelitian ini ingin memahami kenyataan sosial menurut apa adanya, mencari sifat yang paling dasar dari kenyataan sosial, yaitu konstruksi sosial yang dilakukan oleh perempuan dan anak sebagai pekerja dalam masyarakat Industri perikanan, menurut pandangan subjektif dan mengetahui kesadaran seseorang yang langsung terlibat dalam peristiwa sosial bukan menurut orang lain yang mengamati. Pendekatannya cenderung nominalis, anti-positivis dan idiografis. Kenyataan sosial, seperti halnya tindakan sosial yang dilakukan secara sengaja muncul karena dibentuk oleh kesadaran dan tindakan seseorang. Karenanya mereka berusaha menyelami jauh ke dalam kesadaran dan subjektivitas pribadi manusia untuk menemukan pengertian apa yang ada di balik kehidupan sosial.

Penelitian ini mengambil setting sosial di beberapa kecamatan yang terletak di wilayah pesisir Kabupaten Pasuruan, Provinsi Jawa Timur. Penelitian dilakukan dengan metode kualitatif tipe penelitian deskriptif menggunakan purposive sampling. Melakukan observasi dan wawancara mendalam pada 10 keluarga, setting penelitian dipilih pada Kecamatan yang menjadi wilayah dominan untuk industri perikanan di Kabupaten Pasuruan yaitu Kecamatan Lekok, Kecamatan Grati dan Kecamatan Rejoso dengan jumlah perempuan dan anak berada pada masa produktif tertinggi. Penentuan lokasi berujung hingga menemukan keluarga nelayan, baik itu perempuan (yang bersatus sebagai istri nelayan) ataupun anak nelayan dan memungkinkan keduanya di Kabupaten

3W Lawrence Neuman, Social Research Methods: Qualitative and Quantitative Approaches (Harlow, UK: Pearson Education Limited, 2014), 92. 
Pasuruan yang terlibat dalam aktivitas industri perikanan sebagai subjek penelitian. Hal ini dilakukan dengan maksud untuk memperbanyak informasi yang diperoleh.

Analisis data dilakukan dengan melakukan model analisis interaktif yang dikembangkan oleh Miles dan Huberman. ${ }^{4}$ Model analisis interaktif terdiri atas pengumpulan data, reduksi data, sajian data, dan penarikan kesimpulan.

\section{B. Profil Pekerja Perempuan di Industri Perikanan}

Masuknya pekerja perempuan yang bekerja di dalam sektor industrydi pesisir pantai Pasuruan selain didasari dengan mengangkat partisipasi kerja bagi penduduk di sekitaran wilayah pantai juga dengan tujuan menekan pengeluaran untuk membayar buruh (labor-cost). Di samping itu, perusahaan atau pelaku industri pengolahan ikan di Pasuruan juga dapat berhemat karena tidak perlu memberi tunjangan sosial karena tidak ada tanggungan keluarga. Berdasarkan hasil observasi yang dilakukan, buruh laki-laki harus dibayar lebih mahal karena laki-laki dianggap sebagai kepala keluarga yang menanggung hidup keluarganya. Buruh laki-laki mendapatkan tunjangan kesehatan yang mencakup dirinya sendiri, seorang istri dan dua orang anak. Tetapi buruh perempuan selalu dianggap lajang, sehingga ia hanya mendapat tunjangan kesehatan untuk dirinya sendiri. Ada pengecualian bagi perempuan yang berstatus janda. Ia akan mendapatkan tunjangan kesehatan yang mencakup tanggungannya, yaitu 2 anak maksimal.

Perempuan yang bekerja di sektor perikanan di Pasuruan sebagian besar adalah tenaga produktif yang rata-rata usianya berada dalam rentang usia 1855 tahun sebanyak 34 orang yang seharusnya diperlakukan sesuai ketentuan dalam Undang-Undang Ketenagakerjaan Nomor 13 Tahun 2003, berbagai hak buruh perempuan telah dilindungi. Seperti hak menstruasi (Pasal 81), cuti hamil, melahirkan, dan keguguran (Pasal 82), serta hak menyusui (Pasal 83). Namun, di sektor perikanan, pasal yang tersebut masih dilanggar bahkan diabaikan. Dalam industri pengolahan ikan yang berjalan dalam skala kecil

${ }^{4}$ B. Mathew MIles dan A. Michael Huberman, Analisis Data Kualitatif: Buku Sumber tentang Metode-metode Baru (Jakarta: UI Press, 1992). 
hingga menengah ini, berdasarkan hasil wawancara, sebagian besar pekerja perempuan justru tidak mengetahuinya, atau bahkan belum pernah mendengarnya. Bagi mereka, yang terpenting bukanlah mendapatkan izin atau cuti sebagaimana yang diatur dalam Undang-Undang Ketenagakerjaan namun lebih kepada bagaimana gaji atau upah yang diterima dapat digunakan sebagai pemenuhan kebutuhan hidup sehari-hari bagi keluarga (subsistensi) setiap harinya.

Dalam perspektif gender, pemberian upah yang rendah bagi pekerja perempuan disebabkan karena secara umum perempuan diposisikan sebagai pekerja yang bersedia diberi upah rendah, karena bukan penghasilan utama dan mereka hanya merupakan pencari nafkah kedua atau pekerjaan sampingan selain suami yang menjadi nelayan di wilayah Pasuruan. Selain itu adanya anggapan bahwa pekerja perempuan jam kerjanya sangat fleksibel dan memiliki tempat tinggal yang tidak jauh dari lokasi industri. Hal inilah yang menyebabkan terjadinya diskriminasi jenis kelamin dan pemiskinan perempuan.

Dalam industri perikanan di Pasuruan, secara umum tidak ada wage-gap antara buruh perempuan dengan laki-laki. Rata-rata perempuan dan lelaki menerima upah berdasarkan ketentuan upah minimum kota atau kabupaten. Namun demikian menunjukkan kesenjangan upah antara buruh laki-laki dengan perempuan. Kesenjangan itu bisa jadi disebabkan perbedaan tunjangan yang didapat oleh buruh perempuan dengan laki-laki. Hasil temuan bahwa buruh perempuan mengalami diskriminasi dalam bentuk lain. Pertama, buruh perempuan yang telah menikah selalu dianggap lajang atau perusahaan hanya bersedia menerima buruh perempuan lajang. Kedua, hak buruh perempuan disamaratakan dengan hak laki-laki atau hak-hak reproduksi perempuan kerap diabaikan. Tidak ada sistem pengupahan yang baku atas pengolahan hasil ikan ini karena pembayaran hasil kerja dilihat berdasarkan satuan yang ditetapkan oleh pemilik industri secara sepihak.

Dari hasil observasi yang dilakukan, kegiatan harian yang dilakukan oleh pekerja perempuan di industri pengolahan ikan dan hasil laut juga diuraikan melalui bantuan Tabel 1 .

Dari Tabel 1, dapat kita ketahui bahwa rerata untuk setiap pekerjaan yang dilakukan oleh pekerja perempuan mendapatkan upah yang sangat sedikit 
dibandingkan dengan jumlah atau kuantitas dari setiap item pekerjaan yang dilakukan. Dalam sebuah wawancara, perempuan pekerja di industri pengolahan ikan mengatakan bahwa setelah ikan sudah bersih dan siap jual, maka akan dijual ke tengkulak yang sudah siap untuk memasarkan ke kota-kota besar mulai di sekitar Pasuruan seperti Surabaya, Malang, Jember. Kepada para perempuan pekerja tersebut, beberapa tengkulak mengatakan ikan yang sudah siap jual akan dipasarkan hingga ke Jakarta, Makassar dan Manado.

Tabel 1.

Aktivitas Harian Pekerja Perempuan di Industri Pengolahan Ikan di Pasuruan

\begin{tabular}{clcl}
\hline No. & \multicolumn{1}{c}{ Kegiatan } & $\begin{array}{c}\text { Waktu Kerja } \\
\text { (kondisional) }\end{array}$ & Satuan Hasil \\
\hline 1 & Memotong Kepala Ikan & Setiap Hari & $60.000 / 20 \mathrm{~kg}$ \\
2 & Membuang isi perut ikan & Setiap Hari & $60.000 / 20 \mathrm{~kg}$ \\
3 & Jemur ikan & Setiap hari & $25.000 / 10 \mathrm{~kg}$ \\
4 & Menguliti atau membersihkan sisik ikan & Setiap hari & $2.500 / \mathrm{kg}$ \\
5 & Memilah ikan & Setiap hari & $1.500 / \mathrm{kg}$ \\
\hline
\end{tabular}

Sumber: Data Primer, diolah

Keterikatan antara pekerja perempuan dengan industri pengolahan ikan terjalin kuat karena perempuan yang notabene penduduk lokal juga sangat membutuhkan pekerjaan ini untuk membantu pemenuhan kebutuhan hidup sehari-hari. Jadi mau tidak mau, pekerjaan dengan risiko apapun di dalam pengolahan ikan ini tetap dilakukan. Seperti halnya hasil wawancara dengan salah seorang informan yang bernama Ibu Jumaliah:

"Di manapun perempuan bekerja itu sebenarnya hukumnya sunnah tetapi kita ini butuh uang jadi saat ini tidak ada pilihan lain untuk bekerja. kalau dirasakan, bekerja di sini yaa bebannya berat... lelah tapi hanya dibayar tidak banyak kalau dibandingkan dengan buruh rokok. Tapi yaa, harga ikan di sini kan memang tidak semahal harga barang pabrikan jadi syukur masih diberi rejeki daripada di rumah saja. Bekerja di sini paling senang karena semua karyawannya tetangga jadi sudah seperti saudara sendiri tapi sedihnya kalau stok ikan mulai menipis dan nelayan belum dapat ikan lagi, karena itu akan menghambat pekerjaan kami. Terkadang, tengah malam pun kami harus kembali ke sini (pengolahan ikan) karena harus segera kejar setoran juga, supaya lekas dapat uang. Demi uang, untuk bisa makan dan belanja yaa harus kuat menahan rasa kantuk."

5Jumaliah, “Wawancara," 19 Desember 2017, pk. 15.30. 
Berdasarkan hasil wawancara yang dilakukan kepada Ibu Simona, lebih jauh dijelaskan latar belakang atau motif yang mendasari partisipasi perempuan di daerah pesisir untuk menjadi pekerja industri perikanan sebagai berikut:

"Saya berani berangkat untuk kerja di sini (di pengolahan ikan) diajak oleh tetangga saya, yang pertama karena motivasi saya untuk mempunyai uang yang lebih banyak lagi, tau sendiri kan kalau pekerjaan nelayan itu bergantung selalu, kalau tidak dengan alam... yaa, dengan kapalnya atau dengan yang menemani, kapan uangnya ngumpul kalau hanya sedikit sedikit terus. Yang kedua karena saya harus membiayai keluarga karena di rumah saya ada ibu saya yang tinggal serumah dengan keluarga saya. beliau sakit-sakitan dan anak saya masih kecil semua,yang ketiga karena banyak teman-teman saya yang bekerja di sini banyak yang sukses (bisa menabung dan ikut arisan yang beragam, bisa membeli perhiasan sampai daftar umroh), dan saya ingin seperti mereka."6

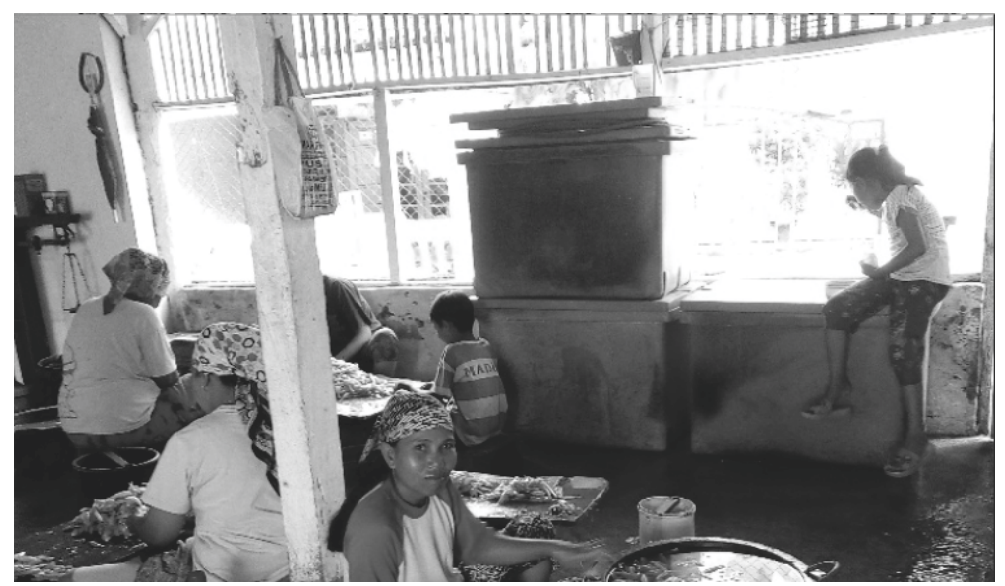

Gambar 1.

Kegiatan yang dilakukan oleh pekerja perempuan dan anak di Industri pengolahan ikan, Lekok, Pasuruan. Sumber: Dokumentasi pribadi, diambil pada 21 Desember 2017, pukul 14.50

\section{Profil Pekerja Anak di Industri Perikanan}

Dalam perkembangan industri, anak adalah sumber daya potensial yang dipandang dapat mendatangkan profit yang lebih besar bagi pelaku industri. Anak sering menjadi sumber penghasilan yang sangat penting karena memiliki

'Simona, “Wawancara,” 20 Desember 2017, pk. 12.15. 
tenaga yang mumpuni untuk mengerjakan berbagai pekerjaan terkait dengan pengolahan ikan. Bahkan dalam banyak hal, pekerja anak dipandang sebagai mekanisme bertahan hidup yang mampu mengeliminasi tekanan kemiskinan yang tidak terpenuhi dari hasil kerja orang tua.

Berdasarkan hasil wawancara, keterlibatan anak dalam kegiatan ekonomi juga karena adanya dorongan untuk membantu meringankan beban orang tua, bekerja untuk mendapatkan penghormatan dari masyarakat, juga keinginan untuk dapat menikmati hasil usaha kerja dalam pemenuhan kebutuhannya sendiri. Akan tetapi sebab terbesar yang mendorong anak-anak bekerja adalah tuntutan orang tua dengan tujuan mendapat tambahan pemasukan bagi keluarga. Anak-anak seringkali tidak dapat menghindar untuk tidak ikut terlibat dalam pekerjaan.

Faktor kemiskinan dianggap sebagai pendorong utama anak untuk bekerja. Kemiskinan secara ekonomi telah banyak menciptakan terjadinya pekerja anak. Orang tua "terpaksa” memobilisasi anak-anaknya sebagai pekerja untuk membantu ekonomi keluarga. Pada titik inilah munculnya kerawanan, sebab anak-anak bisa berubah peran dari "sekadar membantu" menjadi pencari nafkah utama. Pekerja anak tidak hanya disebabkan oleh kemiskinan, tetapi juga menyebabkan "pemiskinan", artinya anak-anak yang bekerja dan tidak mengecap pendidikan akan tetap hidup di dalam kondisi kemiskinan di kemudian hari. Akibat lebih jauh, generasi berikutnya akan tetap miskin dan tidak berpendidikan.7

Berdasarkan hasil penelitian, pemilik industri pengolahan ikan masih mementingkan aspek pendidikan walaupun sekitar 8 anak dari pekerjanya yang masih sekolah. Dia memilih anak anak untuk menjadi pekerja di pengolahan ikan karena pekerjaan tersebut dianggap mudah dilakukan oleh warga lokal yang tinggal di pesisir Pasuruan, sehingga tidak begitu sulit mendapatkan pekerja, dari 8 anak yang bekerja di pengolahan ikan tersebut, 4 orang tersebut sedang sekolah menengah pertama dan sekolah menengah atas, sisanya berada di jenjang sekolah dasar. Sistem pembagian pekerjaannya di-

\footnotetext{
${ }^{7}$ Noer Effendi Tadjhoedin, "Buruh Anak Fenomena di Kota dan Pedesaan," dalam Buruh Anak di Sektor Informal-Tradisional dan Formal Sumberdaya Manusia (Jakarta: Yayasan Tenaga Kerja Indonesia, 1992).
} 
lakukan secara shift, karena beberapa sekolah tempat pekerja anak menempuh pendidikannya juga ada yang masuk pagi hari dan ada yang masuk siang hari. Bagi pekerja anak, pemilik usaha pengolahan ikan juga memberlakukan lembur pada malam hari.

Dilihat dari fenomena tersebut orang tua yang mengijinkan anaknya untuk bekerja masih belum mampu untuk memikirkan masa depan anaknya karena anak yang seharusnya sekolah justru bebannya ditambah dengan bekerja. Apa yang dilakukan oleh setiap anggota keluarga dalam keluarga nelayan di Pasuruan, Jawa Timur merupakan mekanisme survival untuk dapat memiliki kehidupan yang berkelanjutan. Temuan Penelitian lainnya juga menunjukkan bahwa pekerja anak merupakan fenomena yang sudah biasa bagi kalangan masyarakat nelayan di sekitar pesisir pantai di Pasuruan yang dilakukan saat anak anak nelayan memasuki usia 6 tahun, bahkan hal ini dianggap sebagai rejeki untuk membantu keluarga, sebagaimana yang disampaikan oleh Nisak:

"Alhamdulillah, saya bisa bantu ebok (ibu) dan kakak saya bekerja di sini (pengolahan ikan) sepulang sekolah mulai saya kelas 5 SD, sekitar 4 tahun lalu. sekarang saya kelas 1 SMA, umur saya 16 tahun. tidak terlalu sulit untuk membagi waktu antara kerja dan sekolah karena saya sudah terbiasa dengan rutinitas ini, pulang sekolah, saya biasanya mengerjakan tugas rumah atau tugas sekolah dulu lalu berangkat kerja. Enaknya bekerja di sini karena tidak ada batasan jam kerja, sistemnya bisa shift tapi borongan. Yang penting bisa dapat uang untuk bantu bayar sekolah atau untuk uang saku. Sejak bekerja, saya jarang meminta uang kepada orang tua karena kan saya tahu kalau saya dapat uang, saya bisa menghitung sendiri uang yang saya dapatkan dari pekerjaan saya jadi enak. Dengan bekerja, paling tidak sebagai anak nelayan yang pendapatannya tidak menentu bisa bergantung kepada diri sendiri, tidak minta ke orang tua."

Berdasarkan wawancara yang dilakukan dengan pemilik industri juga menyampaikan bahwa tidak pernah memaksa pekerjanya untuk setiap hari bekerja, karena pemilik sendiri juga selalu memberikan motivasi kepada pekerjanya yang masih sekolah untuk mementingkan sekolah daripada bekerja dan diharapkan pekerjanya ada yang bisa sampai di perguruan tinggi agar nantinya mau kembali bekerja di daerah pesisir pantai untuk membantu industri pengolahan ikan semakin berkembang. pemilik industri pengolahan ikan di Pasuruan ini juga memiliki anak kandung yang masih berusia sekolah,

8Nisak, “Wawancara,” 20 Desember 2017, pk 14.00. 
yang terkadang juga ikut membantu orang tuanya untuk mengolah hasil laut apabila anaknya libur ataupun memiliki waktu senggang sehingga pemilik industri pengolahan ikan tidak akan memaksa mengenai pelaksanaan jam kerja, asalkan pekerjaan yang seharusnya dilakukan selesai dan dibayar berdasarkan upah yang sudah menjadi kesepakatan antara pekerja anak dan pemilik usaha pengolahan ikan.

Terkait upah yang diterima, memang ada perbedaan yang diberikan terhadap pekerja anak dan pekerja perempuan. Pekerja anak dibayar lebih murah dengan alasan ada kelonggaran untuk mengerjakan pengolahan ikan, ia bisa membawa pulang pekerjaannya jika ia mau dan diperkenankan oleh ibunya atau ayahnya untuk melanjutkan pekerjaan terebut di rumah sehingga hal ini dianggap tidak banyak menyita waktu yang dimiliki anak untuk berada di rumah. Dengan alasan inilah pemilik usaha pengolahan ikan menganggap bahwa dirinya memberikan fleksibilitas kepada anak-anak untuk bekerja secara sukarela, dengan tanpa paksaan sehingga sistem pembayaran yang dimiliki oleh pekerja anak juga borongan yang nantinya akan dihitung kembali per satuan ember.

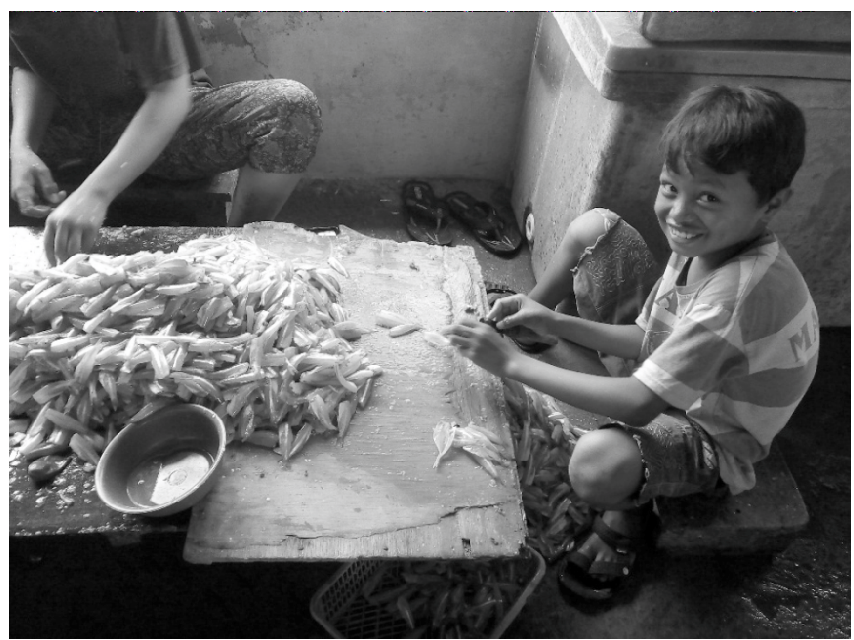

Gambar 2

Aktivitas pekerja anak bersama para pekerja perempuan saat memotong kepala ikan. Sumber: Dokumentasi pribadi, diambil tanggal 20 Desember 2017, pukul 13.30 
Tidak ada perbedaan upah yang diterima antara pekerja anak yang berjenis kelamin laki-laki ataupun perempuan dalam industri pengolahan ikan. Setiap pekerja anak yang bekerja di sebuah industri pengolahan ikan tidak bisa memilih pekerjaan mana yang harus dilakukan, tergantung kepada pekerjaaan apa yang belum selesai dilakukan, itulah yang harus dikerjakan dan diselesaikan setiap harinya. Sebagaimana dengan bantuan Tabel 2 dapat diketahui mengenai berbagai pekerjaan (task job) yang dilakukan oleh pekerja anak di pesisir Pasuruan dalam industri pengolahan ikan.

Tabel 2.

Aktivitas Harian Pekerja Anak di Industri Pengolahan Ikan, Pasuruan

\begin{tabular}{|c|c|c|c|}
\hline No. & Kegiatan & $\begin{array}{l}\text { Waktu Kerja } \\
\text { (kondisional) }\end{array}$ & Satuan Hasil \\
\hline 1 & Memotong Kepala Ikan & Setiap Hari & $\begin{array}{l}30.000 / \text { ember kecil } \\
(+/-10 \mathrm{~kg}) \\
50.000 / \text { ember besar } \\
(+/-20 \mathrm{~kg})\end{array}$ \\
\hline 2 & $\begin{array}{l}\text { Membuang isi perut } \\
\text { ikan }\end{array}$ & Setiap Hari & $\begin{array}{l}30.000 / \text { ember kecil } \\
(+/-10 \mathrm{~kg}) \\
50.000 / \text { ember besar } \\
(+/-20 \mathrm{~kg})\end{array}$ \\
\hline 3 & Jemur ikan & Setiap hari & $20.000 / 10 \mathrm{~kg}$ \\
\hline 4 & $\begin{array}{l}\text { Menguliti atau mem- } \\
\text { bersihkan sisik ikan }\end{array}$ & Setiap hari & $1.500 / \mathrm{kg}$ \\
\hline 5 & Memilah ikan & Setiap hari & $1.000 / \mathrm{kg}$ \\
\hline
\end{tabular}

Sumber: Data Primer, diolah

Hasil wawancara yang dilakukan kepada pekerja anak menunjukkan bahwa mereka sangat terbantu dengan kemampuan untuk melakukan aktivitas dalam pengolahan ikan sehingga memiliki kontribusi dalam kehidupannya, baik sebagai anak nelayan maupun keluarga nelayan. Hal ini sejalan dengan wawancara yang dilakukan dengan Ferdi, salah satu pekerja anak yang berada di jenjang sekolah dasar:

"Saya kelas 4 sekarang, umur saya 9 tahun. Rumah saya di Jatirejo, hanya 200 meter, saya kesini naik sepeda tapi kadang saya jalan. Saya bekerja di sini (pengolahan ikan) karena disuruhsama ibuk saya untuk membantu orang tua. Kadang-kadang masih kepingin untuk ikut bermain dengan teman-teman tapi kata ibu, saya harus bantu ibuk 
cari uang supaya bisa sekolah, bisa untuk membeli jajan karena ibuk saya uangnya tidak banyak. Enaknya bisa bekerja, saya dapat uang, saya juga bisa tahu caranya mengolah ikan karena kan di sini banyak ikan. Kalau sudah tahu caranya membersihkan ikan atau membuat olahan ikan nanti kalau besar kita bisa dapat uang banyak, bisa untuk naik haji. Kata ibuk saya, kalau dari kecil sudah pinter di sini (industri pengolahan ikan) nanti kalau besar bisa usaha sendiri, Aamiin. Saya dan 3 kakak saya semua bekerja di sini karena kalau Cuma menunggu bapakyang pergi ke laut, dapat uangnya lama." ${ }^{\prime 9}$

\section{Dualisme Gender Pekerja Perempuan dan Anak di Industri Perikanan}

Dualisme gender muncul dalam sistem patriarkhi yang mengurung lakilaki dan perempuan pada kotak-kotak identitas yang tertutup rapat antara satu dengan yang lain. Tipologi ini diperparah oleh pemaknaan identitas perempuan berdasarkan sudut pandang laki-laki. Perempuan didefinisikan secara sosial, oleh dan untuk kepentingan laki-laki. Identitas perempuan adalah mahluk yang bukan laki-laki. Jika misalnya laki-laki beridentitas rasional, maskulin dan publik, maka perempuan adalah beridentitas emosional, feminin, dan domestik. Konsepsi identitas ini kemudian mengarah pada adanya dikotomi, konsepsi kedua dari metafisika Barat.

Dalam konteks peran gender, pemahaman antara ideologi patriarkhi dan dikotomi, terletak pada adanya dominasi satu pihak atas pihak lain, yang lahir dari dikotomi ini. Kosekusesinya, relasi laki-laki dan perempuan merupakan relasi dominasi. Posisisuperior yang dimiliki oleh identitas laki-laki, yakni rasional, maskulin, dan petualang publik, dianggap merupakan kualitas, sifat dan perilaku yang melekat pada identitas tersebut. Kualitas rasionalitas dan maskulinitas laki-laki, diyakini lebih unggul dari kualitas emosionalitas dan feminitas yang dimiliki oleh perempuan. Konsekuenasi dari keyakinan ini adalah lahirnya klaim masyarakat patriarkhi bahwa sudah kodratnya, laki-laki memiliki posisi superior, dominatif, dan menikmati posisi-posisi istimewa dan sejumlah privelege lainnya atas perempuan.

Peran ganda merupakan dua peran yang dijalankan oleh seorang saja dalam menjalankan suatu tugas yang memang sudah menjadi hal yang dikerjakannya (bekerja) dan juga salah satu peran itu telah menjadi kodrat yang

9Ferdi, “Wawancara," 20 Desember 2017, pk. 15.00. 
memang telah melekat dari dahulu pada diri dan tanggung jawabnya di dalam sebuah keluarga. Dalam keluarga konvensional, suami bertugas mencari nafkah dan istri yang mengurusrumah tangga. Tetapi kini, dengan tumbuhnya kesempatan bagi perempuan bersuami untuk bekerja, pada pola kekeluargaan segera berubah danmuncul apa yang disebut sebagai dualisme karir. Dualisme (persamaan) karir terjadi bila suami maupun istri sama-sama bekerja dan mengurus rumah tangga secara bersama pula. Di dalam hubungannya dengan posisi masing-masing, setiap pasangan suami istri memiliki cara yang berbeda di dalam mengatur peranannya dalam pekerjaan dan rumah tangga. Perempuan yang bekerja secara part time umumnya menganggap bahwa pekerjaan hanyalah sekedar rutinitas yang dijalani dan hanya menduduki prioritas kedua di bawah kepentingan keluarga. Tetapi dalam keluarga dualisme karir egalitarian, suami istri bekerja tidak hanya sekedar mencari nafkah tetapi juga dalam persaingan untuk mendapatkan posisi yang sama dalam pengambilan keputusan serta berbagai aktivitas dalam keluarga. ${ }^{10}$

Dewasa ini keterlibatan perempuan dalam sektor produksi sudah biasa, ada perempuan yang bekerja penuh di luar rumah sama dengan laki-laki. Ada juga sebagian yang lain memilih kerja paruh waktu atau menjadikan rumah tinggal mereka sebagai pusat dari kegiatan perempuan mencari nafkah, seperti berjualan. Bekerja paruh waktuatau penuh, berarti perempuan sudah ikut berperan sebagai pencari nafkah keluarga (produksi), walaupun begitu keterlibatan perempuan di sektor produksi tidak berdampak pada perlakuan yang sama untuk suami dalam mengurus keluarga dan anak. Tugas domestik tetap dianggap kerja istri, suami jarang sekali yang terlibat mengurus rumah tangga dan anak-anaknya secara intens.

Berubahnya pandangan masyarakat dewasa ini terhadap perempuan yang bekerja, kehadiran tenaga kerja perempuan yang semakin banyak dalam sektor industrial dan adanya gerakan emansipasi telah berhasil mendobrak nilai-nilai tradisional yang menganggap tabu kehadiran perempuan dalam dunia industri dan membatasi peran perempuan sebatas rumah tangganya. Hal ini berlaku pula pada konteks pekerja perempuan dan anak pada sektor perikanan di Pasuruan. Seorang istri, ibu dan juga anak-anak yang berada di

10Parker, Brown, and Smith, Sosiologi Industri, 60. 
bawah umur harus membagi waktunya untuk bekerja dan meninggalkan masa bermainnya untuk bekerja, emansipasi serta partisipasi perempuan telah mengubah perspektif dan sikap perempuan mendobrak nilai-nilai patriarkhi dalam tradisi budaya yang selama ini melekat dalam masyarakat.

Peran perempuan tidak lagi hanya menjaga, menjaga anggota keluarga dan rumah akan tetapi juga mencari nafkah membantu suami untuk mencukupi semua kebutuhan hidup sehari-hari dan membantu meningkatkan perekonomian keluarga, dengan menjadi ibu rumah tangga juga menjadi perempuan karir. Ketidakadilan dalam masyarakat menempatkan perempuan dalam sektor domestik. Masyarakat memandang perempuan mempunyai sifat lemah lembut, emosional. Perempuan secara kodrat memiliki sifat keibuan dapat melahirkan sehingga mereka mempunyai kewajiban untuk mengasuh anak-anak mereka. Perempuan dalam melahirkan anak-anak mereka dan memikul tanggung jawab, terutama dalam mengurus rumah dikaburkan oleh pandangan tentang kerja reproduksi yang menempatkan sebagai bagian "alami" memandangnya sebagai aspek peran gender yang ditentukansecara sosial serta dikaburkan oleh pandangan mengenai kerja yang sinonim dengan kerja dalam lapangan kerja purna waktu yang memperoleh upah. ${ }^{11}$

Perempuan memiliki sifat "alami" (nature) sesuai dengan kodratnya bahwa perempuan mempunyai kewajiban melakukan kegiatan-kegiatan di sektor domestik dan perempuan diusahakan untuk berbudaya (culture) yang menguntungkan kaum laki-laki. Usaha inimenyebabkan terjadinya proses produksi dan reproduksi mengalami ketimpangan hubungan antara laki-laki dan perempuan (gender gap). Implikasi dari konsep dan akal sehat (common sanse) tentang posisi yang tidak seimbang telah menjadi kekuatan dimana perempuan dianggap orang yang berkiprah dalam sektor domestik sementara laki-lakidi tempatkan sebagai kelompok yang berhak mengisi sektor publik. ${ }^{12}$

Kehidupan antara suami istri memegang peranan penting dalam pembinaan kesejahteraan bersama, secara fisik, materi maupun spiritual, juga dalam meningkatkan kedudukan keluarga dalam masyarakat. Usaha meningkatkan kedudukan keluarga dalam masyarakat juga mencakup menyeleng-

\footnotetext{
${ }^{11}$ Cleeves Julia Mosse, Gender dan Pembangunan (Yogyakarta: Pustaka Pelajar, 1996), 71. ${ }^{12}$ Irwan Abdullah, Sangkan Paran Gender (Yogyakarta: Pustaka Pelajar, 1997), 3-4.
} 
garakan hubungan baik dengan semua keluarga dan lingkungan (keluarga sendiri, keluarga lain yang berasal dari pihak istri maupun suami, rukun tetangga dan lingkungan pekerjaan), ikut serta dalam organisasi masyarakat, mengatur anggota-anggota serumah tangga sehingga masing-masing ikut serta dalam menyelenggarakan kehidupan bersama yang serasi.

Dualisme gender dalam perempuan dan anak nelayan di pesisir Pasuruan dapat dilihat melalui gambaran anggota keluarga yang memiliki tugas dan kewajibannya yang sesuai dengan perannya, namun ada pula seorang yang menjalankan dua peran sekaligus walaupun itu sebenarnya bukan kewajibannya. Peran ganda yang seperti ini juga dijalankan oleh seorang anak-anak yang masih berada di bawah 18 tahun dan mengenyam di pendidikan dasar atau menengah yang diharuskan menjadi pekerja untuk dapat mensupport finansial bagi kebutuhan sekolahnya. Dalam keluarga nelayan, seorang ibu memiliki peran ganda sebagai seorang istri atau ibu untuk suami sekaligus anakanaknya (ibu rumah tangga) dan juga sebagai seorang pekerja mencari nafkah tambahan. Pilihan pekerjaan menjadi pekerja di industri pengolahan ikan dilakukan untuk membantu suaminya mencari nafkah tambahan yang tidak menentu dari hasil melaut.

Walaupun kesempatan kerjanya di bidang non formal, perempuan nelayan yang telah menikah tetap akan memiliki dua peran ganda tersebut sampai kurun waktu yang tak ditentukan untuk memenuhi maupun untuk membantu suami dalam pencarian nafkahnya, tak peduli dalam menjalankan pekerjaan itu sulit ataupun mudah tetap saja dijalani, termasuk dalam menjalani kehidupan menjadi istri nelayan hingga menjadi pekerja di industri pengolahan ikan. Bagi perempuan dan anak pekerja, sebagian besar memang berasal dari wilayah sekitar industri pengolahan ikan di sepanjang pesisir Pasuruan, bekerja adalah halyang sangat penting, dapat pula dikatakan hal yang utama ataupun tujuan utamanya dalam peningkatan perekonomian dan juga peningkatan status sosial keluarganya maupun individunya.

Dalam konteks fenomena pekerja perempuan dan anak di pesisir, turut sertanya anggota keluarga nelayan dalam pekerjaan dan membantu mencari nafkah, dapat diasumsikan bahwa mereka telah bersumbangsih tenaga dan kemampuannya dalam membantu memikul beban perekonomian keluarganya 
bersama suami yang sebagai kepala rumah tangga dan penanggung jawab utama perekonomian keluarga dari semua kebutuhan maupun keperluan keluarganya. Tanpa melupakan tugas dan kewajibannya seorang perempuan yang dengan panggilannya sebagai istri dan ibu rumah tangga tetap menjalankan kewajiban dan tanggung jawab perannya di dalam keluarga dalam konteks yang berbeda dengan yang dianut sebelumnya dalam kerangka budaya patriarkhi.

Seorang istri atau perempuan yang menjadi pekerja di sektor pengolahan ikan tidak lagi mengerjakan peran domestiknya (sebagai ibu rumah tangga seperti memasak, membersihkan rumah, menyiapkan hidangan makanan) dan juga menjalankan peranannya sebagai seorang istri yang melayani suaminya saat akan berangkat melaut untuk mencari ikan dan hasil laut lainnya tetapi ia lebih banyak melakukan tugas dalam mencari nafkah dan pemenuhan kebutuhan fisik serta material bagi keluarganya. Tugas domestik yang harusnya dijalankan oleh seorang ibu atau istri justru lebih banyak dilakukan oleh bantuan anak dan atau dibantu oleh kerabat keluarga yang lainnya yang tinggal serumah. Budaya yang dimiliki oleh masyarakat di Pasuruan sebagian besar didominasi etnis Madura yang berkarakter keras, namun di balik kekerasannya tersebut dalam beberapa konteks juga sangat sensitif seperti halnya tentang keluarga, agama atau pendidikan. Rata-rata masyarakat di Pasuruan juga menggunakan bahasa Madura sebagai bahasa pengantar selain bahasa Indonesia.

\section{E. Konstruksi Sosial Pekerja Perempuan dan Anak di Industri Perikanan}

Ekternalisasi sebagai proses pewacanaan perempuan sebagai pekerja, tahap yang paling awal adalah suatu pencurahan manusia secara terusmenerus ke dalam dunia. Dalam fenomena pekerja perempuan pada keluarga nelayan, ekternalisasi terjadi ketika masyarakat memberikan sebuah wacana tentang pekerja dalam sektor perikanan. Individu disosialisasikan oleh orang orang di sekitarnya bahwa pekerjaan sebagai buruh terutama bagi mereka yang berstatus sebagai istri atau anak merupakan sesuatu hal yang tidak baik. Ekternalisasi ini bermula pada saat individu menangkap pandangan dari masyarakat tentang pekerjaan sebagai babu atau pembantu apalagi letak 
industri masih di sekitar tempat tinggal di Pasuruan. Mayarakat mengatahkan bahwa babu ini adalah tindakan pekerjan yang tidak baik, Hal buruk yang semestinya tidak dilakukan oleh seseorang dalam kehidupanya, dalam hal ini terkait pada lingkungan masyarakat. Informan berkembang dalam latar belakang sosial kehidupan yang berbeda. Namun semua informan mendapatkan sebuah wacana yang sama mengenai pekerjaan sebagai buruh. Walaupun tidak secara langsung diajarkan oleh orang tua atau keluarga, semua berprinsip bahwa pekerjaan sebagai buruh lepas atau serabutan dalam industri pengolahan ikan merupakan hal yang tidak baik dikerjakan sama halnya dengan menjual diri atau juga menjadi orang yang tidak memiliki harga diri karena harus meninggalkan keluarga yang dianggap lebih berharga.

Kehidupan sehari-hari memberikan sesuatu secara objektif, setiap individu lahir dan berkembang dalam sebuah masyarakat yang memilki pengaruh kuat bagi individu. Seperti diungkapkan di atas bahwa pengaruh itu muncul dari keluarga dan masyarakat. Sehingga dari situ anak terlahir dari sebuah kesamaan ideologi dan anak diajarkan dengan pola-pola pengajaran serta tindakan tertentu sehinga anak dapat menerima itu sebagai realitas. Orang tua sebagai pendidik di rumah juga memilki keinginan mengajarkan hal yang baik kepada anaknya. Orang tua menginginkan anak yang bersifat baik, bekerja sebagai buruh dalam industri pengolahan ikan hanya akan mencoreng nama baik keluarga karena jelas bahwa hal itu akan merugikan orang tua. Secara garis besar,orang tua mengetahui tentang aktivitas anaknya yang selalu menginginkan anaknya bergaul di lingkungan yang baik. Maka dari itu pemahaman tentang pekerjaan sebagai pekerja di kawasan lokal, terutama menjadi buruh merupakan sesuatu pekerjaan yang tidak baik dikerjakan oleh seorang perempuan pada awalnya, terutama bagi mereka yang telah berkeluarga. Melalui momentum objektivasi, seseorang mulai melebur dengan banyak individu dan melakukan interaksi. Seseorang membawa pemikiran objektif dari hasil aktivitas ekternalisasinya.

Dengan demikian objektivasi merancang suatu proses dimana dunia sosial menjadi suatu realitas yang mampu menghambat atau juga membentuk partisipasinya. Sebagian besar informan mengaku memilih menjadi pekerja dalam sektor perikanan karena melihat kesuksesan dan berubahnya nasib 
secara ekonomi pada tetangga dan saudara yang juga tinggal di lingkungan sekitarnya. Tindakan perempuan nelayan yang memilih untuk bekerja oleh seluruh informan memilki alasan yang berbeda. Sebagian perempuan memang merasa terpaksa melakukan tindakan tersebut karena melakukan hal di luar kelaziman sebagai seorang istri ataupun ibu yang harusnya, menurut kebudayaan masyarakat etnis Madura lebih cocok untuk di rumah sebagai ibu rumah tangga. namun, disisi lain, informan lain menyatakan bahwa mereka menganggap apa yang dirasakan, saat hidup menjadi istri nelayan yang harus bergantung kepada berbagai aspek, juga sangat melelahkan. Informan lain mengakatakan bahwa menjadi pekerja perempuan di sekitar lingkungan rumah justru menguntungkan bagi mereka,yang memberikan kesempatan untuk aktualisasi diri yang paling tinggi yang dapat dilakukan mengingat beban yang harus ditanggung ketika mereka mulai sulit untuk melakukan akses pada pekerjaan.

Hal tersebut di atas dijelaskan oleh Berger dan Luckman yang mengatakan institusi masyarakat yang tercipta dan dipertahankan atau diubah melalui tindakan dan interaksi manusia. Jadi meskipun masyarakat dan institusi sosial terlihat nyata secara objektif, namun pada kenyatannya semuanya dibangun dalam definisi subjektif melalui proses interaksi. Proses objektivasi tidak pernah berhenti dan terus berlanjut. Bekal pemahaman yang mereka bahwa dari sebuah proses objektivikasi kian mengalami guncangan, bahkan banyak ubahan konsep. Konsep dari yang mengatakan pekerjan sebagai buruh itu tidak baik dan tidak boleh dilakukan oleh perempuan, terutama bagi yang telah berkeluarga kini menjadi absurd. Hal ini terlihat pada sikap masyarakat terhadap pekerja perempuan lainya yang juga bekerja, baik di sektor industri perikanan, pertanian, bahkan manufaktur di wilayah Pasuruan. Menuju sikap tersebut juga dilihat bagaimana seorang menerapkan dalam kehidupan. Seperti seorang perempuan yang berkeluarga, rata-rata memiliki anak sehingga lazimnya cukup berada di rumah dan melakukan berbagai pekerjaan dalam sektor domestik sebagaimana tugas mereka sebagai istri atau bahkan sebagai seorang ibu. Dengan makin maraknya pekerja perempuan, bahkan pekerja anak di wilayah Pasuruan maka di dalam masyarakat, pandangan mengenai "perempuan idaman" seakan-akan tidak lagi relevan. 
Internalisasi pekerja perempuan dan anak pada keluarga nelayan terjadi setelah melalui dua tahap awal dalam sebuah momentum, pada tahap akhir yakni proses intermalisasi. Pada proses internalisasi ini individu melakukan peresapan kembali atas realitas yang terbentuk di masyarakat sebagai struktur yang objektif dan mengaplikasikanya dalam diri sebagai realitas subjektif. Ada dua tahap penting sebelum merujuk pada proses bagaimana pekerja perempuan mengkontruksikan pekerjanya. Tahap tersebut berada pada tahap pengenalan atau pemaknaan awal (ekternalisasi) melihat pemahaman mereka tentang pekerjan dalam industri pengolahan ikan. Lalu yang kedua adalah tahap implementasi, yakni sebuah sikap ketika berada di lingkungan masyarakat. Masing-masing informan memilki pemaknaan berbeda-beda tentang pemahaman akan menjadi pekerja di industri perikanan. Pemaknaan ini diperoleh dari beberapa tahapan yang kemudian membawa mereka pada sebuah keyakinan pemikiran (subjektif) untuk bertindak atas wacana (objektivasi) yang selama ini mereka terima. Pemaknaan akan pekerja perempuan saat seorang perempuan nelayan sebelum menjadi pekerja dan sesudah memasuki dunia pekerjaan di wilayah pesisir Pasuruan mengalami beberapa perubahan. Perubahan yang muncul dipandang sebagai sebuah kritik subjektif, selanjutnya kritik inilah yang kemudian membuat perempuan nelayan sendiri mampu untuk mengkonstruksikan apa dan bagaimana pekerjaan yang dilakoni sebagai pekerja dalam industri pengolahan ikan.

Dari hasil penelitian, ditemukan dua pandangan tentang konstruksi sosial terhadap pekerja perempuan dan anak pada industri pengolahan ikan. Yaitu pekerjaan sebagai sebuah pembuktian dan kebanggaan karena perempuan bisa keluar dari sektor domestik dan masuk ke ranah publik, selain itu belum tentu semua orang dapat memiliki kesempatan untuk mendapatkan uang dengan hasil keringat sendiri yang berakibat pada munculnya gengsi, meningkatnya kemampuan secara finansial dan pemenuhan kebutuhan hidup dalam keluarga. Sedangkan beberapa informan memaknai pekerjaan sebagai akibat dari sebuah kebutuhan dimana sudah tidak ada pilihan lagi untuk memenuhi kebutuhan hidup dalam jangka panjang selali kembali menjadi buruh migran. Anggapan bahwa menjadipekerja dalam sektor industri merupakan sebuah pekerjaan yang tidak baik dilakukan oleh perempuan nelayan menge- 
rucut pada dua pandangan, konstruksi sosial yang terjadi dalam pekerja perempuan dan anak nelayan di pesisir Pasuruan adalah bekerja di industri pengolahan ikan dilakukan dengan rasa bangga karena mampu keluar dari sistem patriarkhi dan alasan sebuah kebutuhan dalam jangka panjang.

\section{F. Kesimpulan}

Munculnya pekerja perempuan dan pekerja anak dalam indutri pengolahan ikan di Pasuruan, Jawa Timur merupakan sebuah perubahan sosial yang terjadi dalam tatanan masyarakat secara patriarkhis. Terbentuknya konstruksi sosial pada perempuan dan anak di wilayah pesisir Pasuruan merupakan sebuah diskursus dan tantangan bagi masyarakat nelayan yang berada di pesisir Jawa Timur secara umum. Aspek perempuan dan anak yang bekerja pada sektor industri perikanan justru dirasa menjanjikan, sehingga terdapat perbedaan makna bekerja pada masa lalu dengan apa yang terjadi di masa kini berdasarkan konstruksi yang melekat dalam masyarakat sebagai sarana pemenuhan kebutuhan hidup.[s]

\section{Daftar Pustaka}

Abdullah, Irwan. Sangkan Paran Gender. Yogyakarta: Pustaka Pelajar, 1997.

Ferdi. “Wawancara." 2017.

Jumaliah. “Wawancara." 2017.

Kusnadi. Keberdayaan Nelayan dan Dinamika Ekonomi Pesisir. Yogyakarta: ArRuzz Media, 2009.

MIles, B. Mathew, dan A. Michael Huberman. Analisis Data Kualitatif: Buku Sumber tentang Metode-metode Baru. Jakarta: UI Press, 1992.

Mosse, Cleeves Julia. Gender dan Pembangunan. Yogyakarta: Pustaka Pelajar, 1996.

Neuman, W Lawrence. Social Research Methods: Qualitative and Quantitative Approaches. Harlow, UK.: Pearson Education Limited, 2014.

Nisak. "Wawancara." 2017. 
Anggaunitakiranantika

Parker, S. R., R. K. Brown, dan M. A. Smith. Sosiologi Industri. Jakarta: Rineka Cipta, 1992.

Simona. "Wawancara." 2017.

Tadjhoedin, Noer Effendi. "Buruh Anak Fenomena di Kota dan Pedesaan." Dalam Buruh Anak di Sektor Informal-Tradisional dan Formal, Sumberdaya Manusia. Jakarta: Yayasan Tenaga Kerja Indonesia, 1992. 